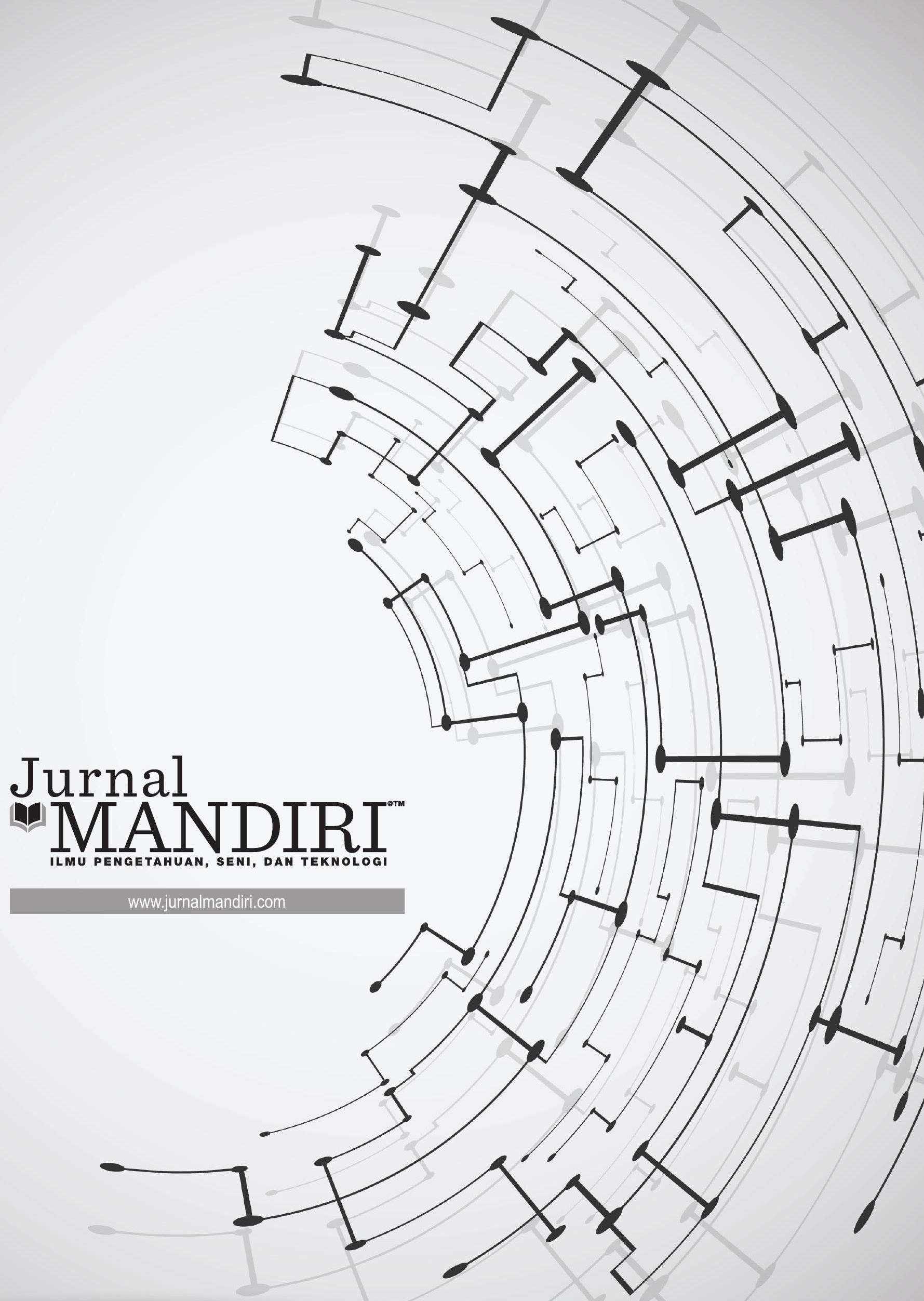


ISSN : 2580-3220, E-ISSN : 2580-4588

J. Mandiri., Vol. 3, No. 2, Desember 2019 (230 - 243)

(C)2018 Lembaga Kajian Demokrasi

dan Pemberdayaan Masyarakat (LKD-PM)

DOI : https://doi.org/10.33753/mandiri.v3i2.84

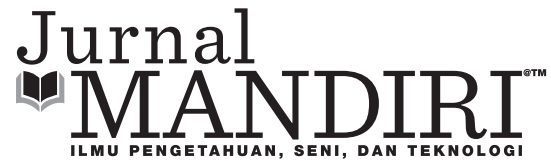

\title{
Pengaruh Harga dan Promosi Terhadap Keputusan Pembelian Pada Story-I Mall Alam Sutera
}

\author{
Iis Noviyanti \\ Fakultas Ekonomi, Universitas Pamulang \\ noviya.115@gmail.com \\ Feb Amni Hayati \\ Fakultas Ekonomi, Universitas Pamulang \\ dosen01657@unpam.ac.id \\ Rizki Saputra \\ Fakultas Ekonomi, Universitas Pamulang \\ rizkys349@gmail.com
}

\begin{abstract}
Abstrak
Tujuan penelitian ini adalah untuk mengetahui pengaruh harga dan promosi terhadap keputusan penjualan pada Story-I Mall Alam Sutera. Pendekatan penelitian yang digunakan dalam penyusunan penelitian ini adalah kuantitatif. Adapun populasi dalam penelitian ini adalah pelanggan pada Story-I Mall Alam Sutera, sedangkan teknik sampel yang digunakan adalah dengan rumus Rao Purba dan jumlah Sampel 100 responden yang mewakili populasi. Metode pengumpulan data metode likert dan interval. Metode yang digunakan untuk menguji dan menganalisis data adalah uji validitas, uji reliabilitas, koefisien korelasi, uji heteroskedastisitas, regresi linier berganda, uji T, uji F, koefisien determinasi, dan uji hipotesis. Hasil analisis data menunjukan harga dan promosi pada Story-I Mall Alam Sutera berpengaruh terhadap keputusan pembelian, hal ini dapat ditunjukan oleh nilai persamaan/model regresi $Y=-6.587+0,386 X_{1}+0,873 X_{2}$ dengan koefisien regresi $X_{1}$ sebesar 0,368, $X_{2}$ sebesar 0,873 dan nilai $t_{\text {hitung }}$ lebih besar dari $t_{\text {tabel }}$ untuk kedua variabel bebas yaitu Harga $X_{1}(2,745>1,985)$ Promosi $X_{2}(6,938>1,985)$. Kontribusi pengaruh harga dan promosi terhadap keputusan pembelian 71,5\% sedangkan sisanya sebesar 28,5\% dipengaruhi oleh faktor lain yang tidak diteliti.
\end{abstract}

Kata Kunci : Strategi Harga, Promosi, Keputusan Pembelian

\begin{abstract}
The purpose of this study was to study the interaction of prices and promotions on sales decisions at Story-I Mall Alam Sutera. This research used in this research is quantitative. The mall in this study is a customer at Alam Sutera Mall Story-I, while the sample technique used is the Rao Purba formula and the number of samples is 100 respondents representing the population. Data collection methods Likert and interval methods. The method used to test and analyze data is the validity test, reliability test, trial, heteroscedasticity test, multiple linear regression, $T$ test, $F$ test, coefficient of determination, and hypothesis testing. The results of data analysis show that prices and promotions in Story-I Mall Alam Sutera affect purchasing decisions, this can be shown by the value of the equation/regression model $Y=-6.587+0.386 X_{1}+0.873 X_{2}$ with a regression coefficient of 0.368 , $X_{2}$ of 0.873 and $t_{\text {value }}$ is greater than $t_{\text {table }}$ for the two independent variables, namely Price $X_{1}(2.745>1.985) X_{2}$ Promotion (6.938> 1.985). The contribution of the price and promotion to the purchase decision was $71.5 \%$ while the remaining $28.5 \%$ was approved by other factors that were not approved.
\end{abstract}


Keywords : Price Strategy, Promotion, Purchasing Decisions

\section{PENDAHULUAN}

Media komunikasi pada era modern seperti sekarang ini membuat setiap individu sudah dapat berkomunikasi tanpa harus memikirkan jarak dan waktu. Salah satu alat bantu komunikasi tersebut adalah dengan menggunakan smartphone. Smartphone Promosi telah merambah ke berbagai media seadalah telepon genggam yang mempunyai kemampuan tingkat tinggi yang sudah menggunakan sistem operasi untuk menjalankan program yang ada didalamnya. Bahkan beberapa smartphone sekarang ini sudah mempunyai fungsi yang menyerupai sebuah komputer dalam hal penggunaan perangkat keras dan perangkat lunak.

Banyaknya produk smartphone yang masuk dipasaran untuk dijual sekarang ini membuat para konsumen melakukan beberapa pertimbangan untuk memilih sebuah smartphone. Salah satunya adalah memikirkan kepraktisan dalam melakukan kegiatan sehari-hari dengan menggunakan smartphone tersebut. Contohnya hampir seluruh aktivitas masyarakat terutama di kota besar sudah didukung oleh smartphone seperti pertukaran informasi berupa $e$-mail yang mudah diakses kapanpun dan dimanapun secara praktis. Tetapi penggunaannya berbeda antar setiap penggunanya. Bagi beberapa orang, penggunaan smartphone bukan hanya sekedar alat untuk berkomunikasi layaknya sebuah telepon genggam biasa, tetapi dapat dimanfaatkan sebagai alat untuk bekerja dengan menggunakan perangkat lunak yang disediakan oleh para pengembang perangkat lunak. Namun, bagi yang lainnya smartphone hanyalah merupakan sebuah telepon genggam yang mempunyai fitur canggih seperti e-mail (surat elektronik), internet, social media, kamera beresolusi tinggi, pemutar musik dan game. Perbedaan penggunaan smartphone oleh setiap orang didasari oleh adanya perbedaan aktivitas sehari-hari, seperti contohnya para eksekutif menggunakan smartphone untuk dapat membantu dirinya dalam mengatur jadwal kegiatannya sehari-hari, sedangkan sebagian besar pelajar sekolah menggunakan smartphone hanya untuk berkomunikasi dan social media.

Seiring berkembangnya zaman dan teknologi, promosi tidaklah sulit untuk dilakukan. perti: televisi, koran, majalah, internet dan radio. Tetapi sebaiknya promosi masa lalu tidak ditinggalkan, seperti penyebaran brosur. Jika ditarik permasalahannya dari satu sisi permasalahan, maka dapat diasumsikan bahwa promosi dilingkungan perusahaan penjualan jasa dan produk sangat diperlukan. Terlihat dari banyaknya promosi yang ditawarkan. Oleh karena itu, dalam perusahaan bagian pemasaran harus memiliki promosi yang efektif agar apa yang dipasarkan meningkat penjualannya. Dengan demikian perusahaan dan kelangsungan hidup perusahaan pun menjadi maju.

Menurut (Tjiptono, 2015) harga merupakan satuan moneter atau ukuran lainnya (termasuk barang dan jasa lainnya) yang ditukarkan agar memperoleh hak kepemilikan atau penggunaan suatu barang atau jasa. Selanjutnya, definisi promosi adalah sarana dimana perusahaan berusaha untuk menginformasikan, membujuk dan mengingatkan konsumen baik secara langsung atau tidak langsung tentang produk dan merek yang mereka jual (Kotler, Keller, Brady, Goodman, \& Hansen, 2012).

Konsumen aktual adalah konsumen yang langsung membeli produk yang ditawarkan pada saat atau sesaat setelah promosi produk tersebut dilancarkan perusahaan dan konsumen potensial adalah konsumen yang berminat melakukan pembelian terhadap produk yang ditawarkan perusahaan dimasa yang akan datang. Sedangkan menurut (Kotler et al., 2012) keputusan pembelian adalah "keputusan yang diambil konsumen untuk melakukan pembelian suatu produk melalui tahapan-tahapan yang dilalui konsumen sebelum melakukan pembelian yang meliputi kebutuhan yang dirasakan, kegiatan sebelum membeli, perilaku waktu memakai, dan perasaan setelah membeli".

Seiring berkembangnya zaman dan teknologi, promosi tidaklah sulit untuk dilakukan. 
Promosi telah merambah ke berbagai media seperti: televisi, koran, majalah, internet dan radio. Tetapi sebaiknya promosi masa lalu tidak ditinggalkan, seperti penyebaran brosur. Jika ditarik permasalahannya dari satu sisi permasalahan, maka dapat diasumsikan bahwa promosi dilingkungan perusahaan penjualan jasa dan produk sangat diperlukan. Terlihat dari banyaknya promosi yang ditawarkan. Oleh karena itu, dalam perusahaan bagian pemasaran harus memiliki promosi yang efektif agar apa yang dipasarkan meningkat penjualannya. Dengan demikian perusahaan dan kelangsungan hidup perusahaan pun menjadi maju. Tetapi, lain halnya dengan yang dialami oleh Story-i Mall Alam Sutera dalam hal penjualan produk beserta target target yang didapatkan pada satu tahun terakhir, berikut ini adalah data penjualan Story-i Mall Alam Sutera periode Januari sampai dengan Desember 2018:

\begin{tabular}{|c|c|c|c|c|}
\hline \multicolumn{5}{|c|}{$\begin{array}{l}\text { Tabel 1. Hasil Regresi dengan White heteroskedasticity } \\
\text { consistent standard errors \& covariance }\end{array}$} \\
\hline BULAN & & TARGET & PENCAPAIAN & PRESENTASE \% \\
\hline JANUARI & $\mathrm{Rp}$ & 1.696.700.000 & $\operatorname{Rp} \quad 1.041 .485 .401$ & $61 \%$ \\
\hline FEBRUARI & $\mathrm{Rp}$ & 1.910 .000 .000 & $\operatorname{Rp} \quad 1.040 .660 .750$ & $54 \%$ \\
\hline MARET & $\mathrm{Rp}$ & 2.028 .605 .517 & Rp $\quad 1.427 .304 .750$ & $70 \%$ \\
\hline APRIL & $\mathrm{Rp}$ & 2.188 .735 .066 & Rp $\quad 1.072 .420 .850$ & $49 \%$ \\
\hline MAY & $\mathrm{Rp}$ & 2.188 .735 .066 & $\operatorname{Rp} \quad 1.077 .052 .150$ & $49 \%$ \\
\hline JUNI & $\mathrm{Rp}$ & 2.188 .735 .066 & Rp $\quad 1.052 .805 .600$ & $48 \%$ \\
\hline JULI & $\mathrm{Rp}$ & 2.188 .735 .066 & $\operatorname{Rp} \quad 1.071 .393 .450$ & $49 \%$ \\
\hline AGUSTUS & $\mathrm{Rp}$ & 2.188 .735 .066 & Rp $\quad 904.464 .650$ & $41 \%$ \\
\hline SEPTEMBER & $\mathrm{Rp}$ & 2.188 .735 .066 & Rp $\quad 957.005 .600$ & $44 \%$ \\
\hline OKTOBER & $\mathrm{Rp}$ & 2.188 .735 .066 & $\begin{array}{ll}\mathrm{Rp} & 870.703 .950\end{array}$ & $40 \%$ \\
\hline NOVEMBER & $\mathrm{Rp}$ & 2.188 .735 .066 & $\begin{array}{ll}\mathrm{Rp} & 728.704 .950\end{array}$ & $33 \%$ \\
\hline DESEMBER & $\mathrm{Rp}$ & 2.188 .735 .066 & Rp $\quad 1.418 .282 .800$ & $65 \%$ \\
\hline
\end{tabular}

Berdasarkan dari tabel penjualan tersebut maka diduga masih terdapat beberapa hal seperti harga dan promosi yang rendah sehingga mengakibatkan keputusan pembelian ikut menjadi rendah. Berdasarkan uraian tersebut, maka penulis tertarik untuk melakukan ppenelitian mengenai harga dan promosi pada Story-i Mall Alam Sutera sehingga penulis memilih judul : Pengaruh Harga dan Promosi Terhadap Keputusan Pembelian Pada Story-I Mall Alam Sutera.

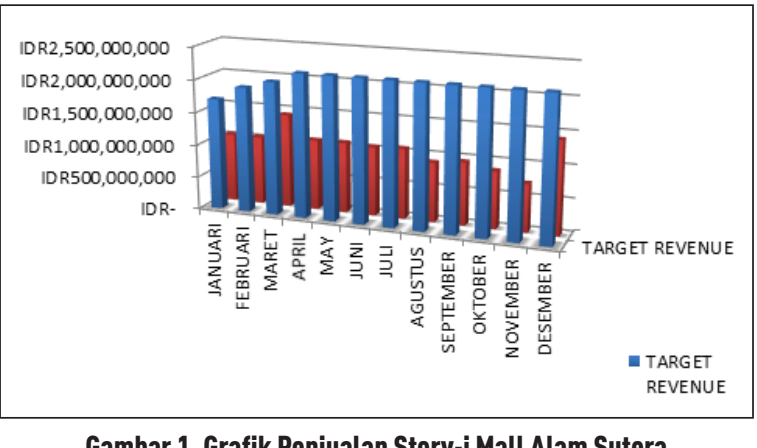

Gambar 1. Grafik Penjualan Story-i Mall Alam Sutera

Sumber : SPV Toko Story-i Mall Alam Sutera

\section{Hipotesis}

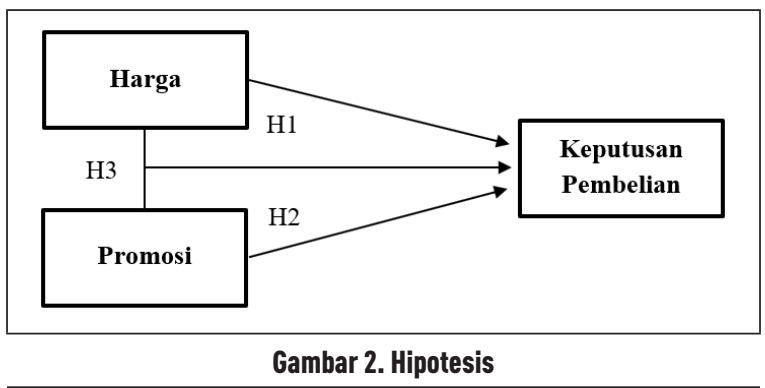

METODE

Adapun ruang lingkup penelitian meliputi :

1. Lokasi Penelitian

Penelitian ini dilakukan di Story-i Mall Alam Sutera, Ground Floor No.G46A Jl.Jalur Sutera Barat Kav.16 Boulevard No.12 Panunggahan Timur, Pinang, Kota Tangerang, Banten. Kode pos 15143.

2. Sifat Penelitian

Metode Penelitian yang digunakan adalah metode bersifat deskriptif kuantitatif yaitu penulis memberikan gambaran jelas tentang harga dan promosi terhadap keputusan pembelian pada Story-I Mall Alam Sutera. Dalam hal ini Story-I Mall Alam Sutera kemudian membandingkan dengan teori yang diperoleh berdasarkan literatur yang ada.

Sedangkan metode penentuan populasi dan sampel yaitu :

1. Populasi

Menurut (Sugiyono, 2016), "Populasi adalah wilayah generalisasi yang terdiri dari obyek atau subyek yang memiliki kualitas dan karakteristik tertentu yang ditetapkan 
peneliti untuk dipelajari yang kemudian ditarik kesimpulannya". Tahap pertama yang dilakukan peneliti dalam pemilihan sample adalah dengan mengetahui data populasinya. Populasi merupakan wilayah generalisasi yang terdiri atas objek atau subjek yang mempunyai karakteristik yang ditetapkan oleh peneliti untuk dipelajari dan kemudian ditarik kesimpulannya. Sesuai dengan judul penelitian yaitu Pengaruh Harga dan Promosi Terhadap Keputusan Pembelian Pada Story-I Mall Alam Sutera, maka populasi penelitian ini adalah pelanggan Penelitian ini dilakukan di Story-i Mall Alam Sutera Jl .Jalur Sutera Boulevard No.12 Panunggahan Timur, Pinang, Kota Tangerang, Banten. Kode pos 15143. Jumlah pelanggan baru dari bulan Januari-Desember tahun 2018 tidak dapat diketahui jumlahnya.

2. Sampel

Menurut (Sunyoto, 2013) sampel adalah sebagian dari populasi yang karakteristiknya hendak diselidiki dan dianggap bisa mewakili keseluruhan populasi. Selanjutnya, menurut (Sugiyono, 2016) "Sampel adalah sebagian dari populasi itu. Populasi itu misalnya penduduk wilayah tertentu, jumlah pegawai pada organisasi tertentu, jumlah guru dan murid di wilayah tertentu dan sebagainya”. Setelah jumlah sampel yang akan diambil dari populasi telah ditentukan selanjutnya pengambilan sampel ditentukan dalam bentuk teknik sampling. (Sugiyono, 2011) "sampel yang baik adalah sampel yang memiliki populasi secara keseluruhan". Adapun penetapan ukuran sampel dalam penelitian ini menggunakan rumus (Sujarweni, 2015), yaitu:

$$
n=\frac{Z^{2}}{4(M o e)^{2}}
$$

Keterangan :

$\mathrm{n} \quad=$ Jumlah Sampel

$\mathrm{Z}$ = Tingkat Keyakinan dalam penentuan sampel $(95 \%=1,96)$

Moe $=$ Margin of error kesalahan maksimum yang bisa ditolerir sebesar 10\% dengan rumus di atas, maka diperoleh perhitungan sebagai berikut:

$$
\begin{gathered}
n=\frac{1,96^{2}}{4(0,1)^{2}} \\
n=96,4
\end{gathered}
$$

Berdasarkan perhitungan rumus diatas, maka jumlah responden yang akan dijadikan sampel penelitian adalah sebanyak 96,4 dibulatkan menjadi 100 responden.

Sementara itu penelitian terdahulu yakni :

1. Pengaruh harga terhadap keputusan pembelian

Berdasarkan hasil penelitian (Senggetang, Mandey, \& Moniharapon, 2019) harga berpengaruh positif dan signifikan terhadap keputusan. Penelitian ini adalah untuk mempelajari lokasi, promosi dan persepsi harga terhadap keputusan pembelian konsumen di Perumahan Kawanua Emerald City Manado. Metode penelitian yang digunakan adalah metode kuantitatif dengan teknik analisis regresi linier berganda. Kuesioner dibagikan kepada para responden yang diadakan sebanyak 50 responden. Hasil adalah lokasi, promosi dan persepsi harga yang disetujui simultan atau parsial terhadap keputusan pembelian.

2. Pengaruh promosi terhadap keputusan pembelian

Berdasarkan hasil penelitian (Kurniawan \& Widajanti, 2016) promosi berpengaruh positif dan signifikan terhadap keputusan pembelian. Analisis menggunakan 100 sampel data dikumpulkan melalui prosedur pengambilan sampel multy stage dengan Banyuwangi dipilih sebagai wilayah. Hasil penelitian menunjukkan bahwa: Harga mempengaruhi keputusan pembelian dan Promosi mempengaruhi keputusan pembelian.

3. Pengaruh harga dan promosi terhadap keputusan pembelian

Menurut hasil penelitian (Aji, N. Setio. Djawahir, 2019) promosi dan harga ber- 
pengaruh positif dan signifikan. Penelitian dilakukan pada konsumen tetap yang bermitra dengan PT. Trakindo Utama Surabaya lebih dari tiga tahun berjumlah 58 responden. Pengumpulan data menggunakan kuesioner dan tinjauan literatur dengan alat analisis WarpPLS versi 6.0. Hasil penelitian menunjukkan pengaruh promosi terhadap keputusan pembelian memiliki pengaruh lemah yang signifikan.

\section{HASIL dan PEMBAHASAN}

Hasil

Harga

Menurut (Tjiptono, 2015), harga merupakan satuan moneter atau ukuran lainnya (termasuk barang dan jasa lainnya) yang ditukarkan agar memperoleh hak kepemilikan atau penggunaan suatu barang atau jasa. Dalam menentukan harga jual, setiap perusahaan tentunya mempunyai tujuan dalam menentukan harga jual berdasarkan tujuan perusahaan. (Kotler, 2005), harga adalah jumlah uang yang ditagihkan untuk suatu jasa atau produk dan jumlah nilai yang dipertukarkan konsumen untuk manfaat yang dimiliki atau menggunakan produk atau jasa tersebut. Selanjutnya menurut (Herawati. Prajanti, 2019), harga adalah jumlah uang yang dibebankan untuk suatu produk atau layanan. Sepanjang sejarahnya, harga telah menjadi faktor utama yang mempengaruhi pilihan pembeli.

\section{Promosi}

Promosi merupakan variabel pemasaran untuk memperkenalkan produk perusahaan kepada konsumen dipasar sasaran. Oleh karena itu, promosi merupakan bentuk komunikasi awal antara perusahaan dan konsumen serta sebagai salah satu media untuk memperkenalkan produk kepada konsumen agar mengetahui akan keberadaan produk perusahaan tersebut. "Definisi promosi adalah sarana dimana perusahaan berusaha untuk menginformasikan, membujuk dan mengingatkan konsumen baik secara langsung atau tidak langsung tentang produk dan merek yang mereka jual" (Kotler et al., 2012). Promosi penjualan merupakan segala kegiatan pemasaran selain personal selling, advertensi dan publisitas, yang merangsang pembelian oleh konsumen dan keefektifan agen seperti pameran, pertunjukan, demonstrasi dan segala usaha penjualan yang tidak dilakukan secara teratur atau kontinyu (Sofjan, 2013). Promosi penjualan adalah persuasi langsung melalui penggunaan berbagai insentif yang dapat diatur untuk merangsang pembelian produkdengan segara dan/atau meningkatkan jumlah barang yang dibeli pelanggan" (Tjiptono, 2011).

\section{Keputusan Pembelian}

Keputusan pembelian yaitu salah satu bentuk perilaku konsumen di dalam menggunakan atau mengkonsumsi suatu produk. Didalam membeli atau memakai suatu produk tertentu untuk melakukan pengambilan suatu keputusan, konsumen akan melalui suatu proses dimana proses tersebut merupakan gambaran dari bagaimana konsumen menganalisis berbagai macam input untuk mengambil keputusan dalam melakukan pembelian. Menurut (Kotler et al., 2012) "Keputusan pembelian adalah keputusan yang diambil konsumen untuk melakukan pembelian suatu produk melalui tahapan-tahapan yang dilalui konsumen sebelum melakukan pembelian yang meliputi kebutuhan yang dirasakan, kegiatan sebelum membeli, perilaku waktu memakai, dan perasaan setelah membeli. Selanjutnya menurut (Herawati. Prajanti, 2019), keputusan pembelian adalah aktivitas individu yang terlibat langsung dalam keputusan untuk melakukan pembelian produk yang ditawarkan oleh penjual.

\section{Hasil Analisis Kuesioner}

Berdasarkan hasil penyebaran kuesioner terhadap 100 responden yang merupakan pelanggan Story-I Mall Alam Sutera, dapat diketahui gambaran tentang jenis kelamin, usia, pendidikan dan pekerjaan responden adalah sebagai berikut:

1. Deskripsi responden berdasarkan jeis kelamin 


\begin{tabular}{|c|c|c|c|}
\hline No & KETERANGAN & JUMLAH & PERSENTASE \\
\hline 1 & Laki-laki & 60 & $60 \%$ \\
\hline 2 & Perempuan & 40 & $40 \%$ \\
\hline \multicolumn{2}{|c|}{ TOTAL } & 100 & $100 \%$ \\
\hline
\end{tabular}

Berdasarkan tabel 2 diatas dapat terlihat responden terdiri dari 60 atau $60 \%$ responden laki-laki dan 40 atau $40 \%$ responden perempuan. Berdasarkan data di atas maka mayoritas pelanggan yang melakukan pembelian di Story-I Mall Alam Sutera adalah laki-laki.

2. Deskripsi Berdasarkan Usia

\begin{tabular}{|c|c|c|c|}
\hline \multicolumn{4}{|c|}{ Tabel 3. Karakteristik Responden Berdasarkan Usia } \\
\hline No & KETERANGAN & JUMLAH & PERSENTASE \\
\hline 1 & $<25$ tahun & 18 & $18 \%$ \\
\hline 2 & 26-35 tahun & 40 & $40 \%$ \\
\hline 3 & $36-45$ tahun & 32 & $32 \%$ \\
\hline 4 & $>46$ tahun & 10 & $10 \%$ \\
\hline \multicolumn{2}{|c|}{ TOTAL } & 100 & $100 \%$ \\
\hline
\end{tabular}

Berdasarkan tabel di atas terlihat bahwa responden didominasi oleh responden berusia $<25$ tahun yaitu sebanyak 18 responden atau $18 \%$, selanjutnya responden berusia $26-$ 35 tahun sebanyak 40 responden atau $40 \%$, responden berusia 36-45 tahun sebanyak 32 responden atau $32 \%$ dan responden berusia $>46$ tahun sebanyak 10 responden atau $10 \%$. Hal ini menunjukkan bahwa pelanggan Story-I Mall Alam Sutera berasal dari berbagai kalangan, baik usia muda maupun usia dewasa.

3. Deskripsi Berdasarkan Pendidikan

\begin{tabular}{|c|c|c|c|}
\hline \multicolumn{4}{|c|}{ Tabel 4. Karakteristik Responden Berdasarkan Pendidikan } \\
\hline NO & KETERANGAN & JUMLAH & PERSENTASE \\
\hline 1 & SD & 0 & $0 \%$ \\
\hline 2 & SMP & 5 & $5 \%$ \\
\hline 3 & SMA/SMK & 24 & $24 \%$ \\
\hline 4 & Diploma & 29 & $29 \%$ \\
\hline 5 & Sarjana & 42 & $42 \%$ \\
\hline \multicolumn{2}{|c|}{ TOTAL } & 100 & $100 \%$ \\
\hline
\end{tabular}

Berdasarkan tabel di atas, maka diketahui bahwa pelanggan pada Story-I Mall Alam Sutera yang memiliki tingkat pendidikan SMP 5 responden, SMA/SMK 24 responden,
Diploma sebanyak 29 responden dan Sarjana sebanyak 42 responden. Data ini menjelaskan jika responden dalam penelitian ini didominasi oleh responden dengan tingkat pendidikan sarjana dengan presentase sebanyak $42 \%$.

4. Deskripsi Berdasarkan Pekerjaan

\section{Tabel 5. Karakteristik Responden Berdasarkan Pekerjaan}

\begin{tabular}{|c|c|c|c|}
\hline NO & KETERANGAN & JUMLAH & PERSENTASE \\
\hline 1 & Mahasiswa & 29 & $29 \%$ \\
\hline 2 & PNS & 3 & $3 \%$ \\
\hline 3 & Wiraswasta & 10 & $10 \%$ \\
\hline 4 & Pegawai Swasta & 41 & $41 \%$ \\
\hline 5 & lbu Rumah Tangga & 17 & $17 \%$ \\
\hline \multicolumn{2}{|c|}{ TOTAL } & 100 & $100 \%$ \\
\hline
\end{tabular}

Berdasarkan tabel diatas, maka diketahuibahwa responden pada Story-I Mall Alam Sutera yang memiliki status sebagai Mahasiswa sebanyak 29 orang atau $29 \%$ dan yang memiliki pekerjaan sebagai PNS sebanyak 3 atau 3\%, wiraswasta sebanyak 10 orang atau $10 \%$, pegawai swasta sebanyak 41 orang atau $41 \%$ dan ibu rumah tangga sebanyak 17 orang atau $17 \%$ Data ini menjelaskan bahwa responden dalam penelitian ini didominasi oleh responden dengan pekerjaan sebagai pegawai swasta.

5. Deskripsi Data Hasil Kuesioner

Pada bagian ini dilakukan analisis deskriptif data kuesioner yang sudah disebarkan pada 100 responden. Berikut rincian penjelasannya:

Harga $\left(X_{1}\right)$

\begin{tabular}{|c|c|c|c|c|c|c|c|c|}
\hline \multicolumn{9}{|c|}{ Tabel 6. Data Kuesioner Harga } \\
\hline \multirow{2}{*}{ No } & \multirow{2}{*}{ PERNYATAAN } & ss & s & KS & TS & STS & \multirow{2}{*}{$\begin{array}{l}\text { JUMLAH } \\
\text { SKOR }\end{array}$} & \multirow{2}{*}{$\begin{array}{l}\text { RATA } \\
\text { RATA } \\
\text { SKOR }\end{array}$} \\
\hline & & 5 & 4 & 3 & 2 & 1 & & \\
\hline \multicolumn{9}{|c|}{ Daftar Harga } \\
\hline 1 & $\begin{array}{l}\text { Katalog harga } \\
\text { produk jelas } \\
\text { ditampilkan dan } \\
\text { mudah dimengerti } \\
\text { konsumen }\end{array}$ & 70 & 140 & 120 & 18 & 2 & 350 & 3,50 \\
\hline 2 & $\begin{array}{l}\text { Harga yang } \\
\text { ditawarkan Story-I } \\
\text { Mall Alam Sutera } \\
\text { terjangkau sesuai } \\
\text { harga pasaran }\end{array}$ & 40 & 156 & 117 & 18 & 5 & 336 & 3,36 \\
\hline 3 & $\begin{array}{l}\text { Harga yang } \\
\text { ditawarkan Story-I } \\
\text { Mall Alam Sutera } \\
\text { sesuai dengan } \\
\text { kualitasnya }\end{array}$ & 75 & 164 & 87 & 24 & 3 & 353 & 3,53 \\
\hline \multicolumn{2}{|c|}{ Nilai rata-rata per indikator } & & & & & & & 3,46 \\
\hline
\end{tabular}




\begin{tabular}{|c|c|c|c|c|c|c|c|c|}
\hline \multicolumn{9}{|c|}{ Diskon } \\
\hline 4 & $\begin{array}{l}\text { Adanya penawaran } \\
\text { diskon di Story-I } \\
\text { Mall Alam Sutera }\end{array}$ & 30 & 40 & 183 & 38 & 4 & 295 & 2,95 \\
\hline 5 & $\begin{array}{l}\text { Diskon yang } \\
\text { diberikan Story-I } \\
\text { Mall Alam Sutera } \\
\text { mempengaruhi } \\
\text { pelanggan untuk } \\
\text { membeli }\end{array}$ & 110 & 288 & 9 & 2 & 2 & 411 & 4,11 \\
\hline \multicolumn{2}{|c|}{ Nilai rata-rata per indikator } & & & & & & & 3,53 \\
\hline \multicolumn{9}{|c|}{ Syarat Pembayaran } \\
\hline 6 & $\begin{array}{l}\text { Story-I Mall } \\
\text { Alam Sutera } \\
\text { menyediakan cara } \\
\text { pembayaran yang } \\
\text { mudah }\end{array}$ & 70 & 168 & 111 & 10 & 2 & 361 & 3,61 \\
\hline \multicolumn{2}{|c|}{ Nilai rata-rata per indikator } & & & & & & & 3,61 \\
\hline \multicolumn{9}{|c|}{ Potongan Harga } \\
\hline 7 & $\begin{array}{l}\text { Adanya cash back } \\
\text { pembelian di } \\
\text { Story-I Mall Alam } \\
\text { Sutera }\end{array}$ & 90 & 164 & 120 & 2 & 0 & 376 & 3,76 \\
\hline 8 & $\begin{array}{l}\text { Adanya potongan } \\
\text { harga apabila } \\
\text { membeli lebih dari } \\
\text { satu produk }\end{array}$ & 30 & 171 & 40 & 4 & 0 & 245 & 2,45 \\
\hline \multicolumn{2}{|c|}{ Nilai rata-rata per indikator } & & & & & & & 3,11 \\
\hline \multicolumn{9}{|c|}{ Kredit } \\
\hline 9 & $\begin{array}{l}\text { Pelanggan tertarik } \\
\text { dengan adanya } \\
\text { penawaran } \\
\text { pembayaran } \\
\text { secara kredit }\end{array}$ & 110 & 312 & 0 & 0 & 0 & 422 & 4,22 \\
\hline \multicolumn{2}{|c|}{ Nilai rata-rata per indikator } & & & & & & & 4,22 \\
\hline \multicolumn{9}{|c|}{ Periode Pembayaran } \\
\hline 10 & $\begin{array}{l}\text { Story-I Mall Alam } \\
\text { memberikan } \\
\text { kemudahan } \\
\text { periode } \\
\text { pembayaran }\end{array}$ & 75 & 104 & 117 & 32 & 4 & 332 & 3,32 \\
\hline \multicolumn{2}{|c|}{ Nilai rata-rata per indikator } & & & & & & & 3,32 \\
\hline & & Tota & a-Pata & & & & & 3,48 \\
\hline
\end{tabular}

Berdasarkan data di atas, diketahui bahwa harga yang ditawarkan oleh Story-I Mall Alam Sutera baik. Hal ini dapat dilihat pada hasil jawaban responden dengan rata-rata skor 3,48 berada pada rentang skor 3,41-4,20 atau masuk pada kategori baik.

\section{Promosi}

\begin{tabular}{|c|c|c|c|c|c|c|c|c|}
\hline \multicolumn{9}{|c|}{ Tabel 7. Data Kuesioner Promosi } \\
\hline \multirow{2}{*}{ No } & \multirow{2}{*}{ PERNYATAAN } & SS & $\mathbf{s}$ & KS & TS & STS & \multirow{2}{*}{$\begin{array}{l}\text { JUMLAH } \\
\text { SKOR }\end{array}$} & \multirow{2}{*}{$\begin{array}{l}\text { RATA- } \\
\text { RATA } \\
\text { SKOR }\end{array}$} \\
\hline & & 5 & 4 & 3 & 2 & 1 & & \\
\hline \multicolumn{9}{|c|}{ Periklanan } \\
\hline 1 & $\begin{array}{l}\text { Promosi yang } \\
\text { ditetapkan Story-I } \\
\text { Mall Alam Sutera } \\
\text { menggunakan } \\
\text { media sosial dan } \\
\text { media online }\end{array}$ & 75 & 132 & 129 & 14 & 2 & 352 & 3,52 \\
\hline 2 & $\begin{array}{l}\text { Adanya konten } \\
\text { edukasi tentang } \\
\text { poduk di Story-l- } \\
\text { Mall Alam Sutera } \\
\text { di media sosial }\end{array}$ & 40 & 136 & 141 & 16 & 3 & 336 & 3,36 \\
\hline
\end{tabular}

\begin{tabular}{|c|c|c|c|c|c|c|c|c|}
\hline 3 & $\begin{array}{l}\text { Informasi } \\
\text { mengenai Story-I } \\
\text { Mall Alam Sutera } \\
\text { mudah didapatkan }\end{array}$ & 70 & 164 & 99 & 20 & 2 & 355 & 3,55 \\
\hline 4 & \begin{tabular}{|l} 
Pesan promosi \\
yang disampaikan \\
di media sosial \\
mudah dipahami
\end{tabular} & 105 & 148 & 69 & 6 & 9 & 337 & 3,37 \\
\hline \multicolumn{2}{|c|}{ Nilai rata-rata per indikator } & & & & & & & 3,45 \\
\hline \multicolumn{9}{|c|}{ Penjualan Tatap Muka } \\
\hline 5 & $\begin{array}{l}\text { Karyawan Story-I } \\
\text { Mall Alam Sutera } \\
\text { memberikan } \\
\text { informasi secara } \\
\text { detail mengenai } \\
\text { produk yang } \\
\text { dijual }\end{array}$ & 100 & 164 & 63 & 22 & 7 & 356 & 3,56 \\
\hline 6 & $\begin{array}{l}\text { Karyawan Story-I } \\
\text { Mall Alam Sutera } \\
\text { dapat mengatasi } \\
\text { masalah } \\
\text { dan keluhan } \\
\text { pelanggan }\end{array}$ & 70 & 160 & 117 & 10 & 2 & 359 & 3,59 \\
\hline \multicolumn{2}{|c|}{ Nilai rata-rata per indikator } & & & & & & & 3,58 \\
\hline \multicolumn{9}{|c|}{ Promosi Penjualan } \\
\hline 7 & \begin{tabular}{|l} 
Pelanggan \\
mendapatkan \\
potongan harga \\
berupa voucher \\
pada saat \\
pembelian
\end{tabular} & 75 & 144 & 144 & 2 & 0 & 365 & 3,65 \\
\hline 8 & $\begin{array}{l}\text { Pelanggan } \\
\text { mendapatkan } \\
\text { hadiah / gift } \\
\text { menarik pada saat } \\
\text { pembelian } \\
\end{array}$ & 0 & 52 & 213 & 28 & 2 & 295 & 2,95 \\
\hline 9 & $\begin{array}{l}\text { Karyawan } \\
\text { memberikan } \\
\text { informasi up to } \\
\text { date mengenai } \\
\text { produk baru }\end{array}$ & 80 & 216 & 60 & 18 & 1 & 375 & 3,75 \\
\hline 10 & $\begin{array}{l}\text { Penjual menemui } \\
\text { pelanggan } \\
\text { langsung untuk } \\
\text { datang ke Story-I } \\
\text { Mall Alam Sutera }\end{array}$ & 40 & 40 & 189 & 34 & 2 & 305 & 3,05 \\
\hline \multicolumn{2}{|c|}{ Nilai rata-rata per indikator } & & & & & & & 3,40 \\
\hline \multicolumn{8}{|c|}{ Total Rata-Rata Keseluruhan } & 3.44 \\
\hline
\end{tabular}

Berdasarkan data di atas, diketahui bahwa promosi yang ditawarkan oleh Story-I Mall Alam Sutera baik. Hal ini dapat dilihat pada hasil jawaban responden dengan rata-rata skor 3,44 berada pada rentang skor 3,41-4,20 atau masuk pada kategori baik.

\section{Keputusan Pembelian}

\begin{tabular}{|c|c|c|c|c|c|c|c|c|}
\hline \multicolumn{9}{|c|}{$\begin{array}{l}\text { Tabel 8. Distribusi Jawaban Responden } \\
\text { Variabel Keputusan Pembelian }\end{array}$} \\
\hline \multirow[b]{2}{*}{ NO } & \multirow{2}{*}{ PERNYATAAN } & SS & s & KS & TS & STS & \multirow{2}{*}{$\begin{array}{l}\text { JUMLAH } \\
\text { SKOR }\end{array}$} & \multirow{2}{*}{$\begin{array}{l}\text { RATA- } \\
\text { RATA } \\
\text { SKOR }\end{array}$} \\
\hline & & 5 & 4 & 3 & 2 & 1 & & \\
\hline \multicolumn{9}{|c|}{ Pilihan Produk } \\
\hline 1 & $\begin{array}{l}\text { Story-I Mall Alam } \\
\text { Sutera menjual } \\
\text { produk yang } \\
\text { berkualitas }\end{array}$ & 95 & 136 & 72 & 28 & 9 & 340 & 3,40 \\
\hline 2 & $\begin{array}{l}\text { Story-I Mall } \\
\text { Alam Sutera } \\
\text { menyediakan } \\
\text { produk yang } \\
\text { beragam }\end{array}$ & 95 & 152 & 75 & 30 & 3 & 355 & 3,55 \\
\hline
\end{tabular}




\begin{tabular}{|c|c|c|c|c|c|c|c|c|}
\hline \multicolumn{2}{|c|}{ Nilai rata-rata per indikator } & & & & & & & 3,48 \\
\hline \multicolumn{9}{|c|}{ Pilihan Merek } \\
\hline 3 & $\begin{array}{l}\text { Terbiasa membeli } \\
\text { produk di Story-I } \\
\text { Mall Alam Sutera }\end{array}$ & 290 & 140 & 21 & 0 & 0 & 451 & 4,51 \\
\hline 4 & $\begin{array}{l}\text { Lebih memilih } \\
\text { membeli produk di } \\
\text { Story-I Mall Alam } \\
\text { Sutera dari pada } \\
\text { ditempat lain }\end{array}$ & 90 & 164 & 78 & 20 & 5 & 357 & 3,57 \\
\hline \multicolumn{2}{|c|}{ Nilai rata-rata per indikator } & & & & & & & 4,04 \\
\hline \multicolumn{9}{|c|}{ Pilihan Penyalur } \\
\hline 5 & $\begin{array}{l}\text { Membeli di } \\
\text { Story-I Mall Alam } \\
\text { Sutera karena } \\
\text { pelayanannya } \\
\text { yang memuaskan }\end{array}$ & 140 & 120 & 54 & 42 & 3 & 359 & 3,59 \\
\hline 6 & $\begin{array}{l}\text { Membeli di Story-I } \\
\text { Mall Alam Sutera } \\
\text { karena lokasinya } \\
\text { yang strategis }\end{array}$ & 175 & 260 & 0 & 0 & 0 & 435 & 4,35 \\
\hline \multicolumn{2}{|c|}{ Nilai rata-rata per indikator } & & & & & & & 3,97 \\
\hline \multicolumn{9}{|c|}{ Jumlah Pembelian } \\
\hline 7 & $\begin{array}{l}\text { Membeli lebih dari } \\
\text { satu produk untuk } \\
\text { keperluan pribadi } \\
\text { dan pekerjaan }\end{array}$ & 80 & 156 & 84 & 22 & 6 & 348 & 3,48 \\
\hline \multicolumn{2}{|c|}{ Nilai rata-rata per indikator } & & & & & & & 3,48 \\
\hline \multicolumn{9}{|c|}{ Waktu Pembelian } \\
\hline 8 & $\begin{array}{l}\text { Membeli pada saat } \\
\text { produk baru saja } \\
\text { release }\end{array}$ & 70 & 180 & 122 & 0 & 0 & 372 & 3,72 \\
\hline \multicolumn{2}{|c|}{ Nilai rata-rata per indikator } & & & & & & & 3,72 \\
\hline \multicolumn{9}{|c|}{ Metode Pembayaran } \\
\hline 9 & $\begin{array}{l}\text { Membeli } \\
\text { produk dengan } \\
\text { pembayaran } \\
\text { secara tunai }\end{array}$ & 145 & 96 & 42 & 40 & 13 & 336 & 3,36 \\
\hline 10 & $\begin{array}{l}\text { Membeli } \\
\text { produk dengan } \\
\text { pembayaran } \\
\text { secara kredit }\end{array}$ & 120 & 120 & 87 & 22 & 6 & 355 & 3,55 \\
\hline \multicolumn{2}{|c|}{ Nilai rata-rata per indikator } & & & & & & & 3,46 \\
\hline & & Total & Rat & turuh & & & & 3,71 \\
\hline
\end{tabular}

Berdasarkan hasil perhitungan diatas, diketahui bahwa keputusan pembelian yang ditawarkan oleh Story-I Mall Alam Sutera baik. Hal ini dapat dilihat pada hasil jawaban responden dengan rata-rata skor 3,71 berada pada rentang skor 3,41-4,20 atau masuk pada kategori baik.

\section{Pembahasan}

\section{Uji Validitas}

Pengujian ini bertujuan mengetahui berapa derajat ketepatan data-data yang digunakan. Dalam melakukan uji validitas peneliti menggunakan program SPSS versi 24 . Uji validitas dilakukan untuk menentukan apakah item valid atau tidak yang dilakukan dengan cara membandingkan nilai $\mathrm{r}_{\text {hitung }}$ pada kolom Corrected Item-Total Correlation dengan nilai $\mathrm{r}_{\text {tabel }}\left(\mathrm{r}_{\text {hitung }}>\right.$ $\mathrm{r}_{\text {tabee }}$ ), maka Item tersebut dinyatakan valid dan sebaliknya, jika nilai $r_{\text {hitung }}$ lebih kecil dari nilai $\mathrm{r}_{\text {tabel }}$ maka Item dinyatakan tidak valid, sehingga harus diperbaiki atau dibuang.

Menurut (Sugiyono, 2013) butir pernyataan dianggap valid nilai $\mathrm{r}_{\text {tabel }}$ untuk 100 responden dengan taraf kesalahan 5\% sebesar 0,197. Uji validitas dalam penelitian ini digunakan untuk menguji kevalidan kuesioner. Validitas menunjukkan sejauh mana ketetapan dan kecermatan suatu alat ukur. Uji validitas terhadap pertanyaan atau pernyataan yang merupakan indikator dari variabel bebas dan terkait, variabel $\mathrm{X}_{1}$ berjumlah 6 poin, dan variabel $\mathrm{X}_{2}$ berjumlah 8 poin dimana Variabel $\mathrm{Y}$ berjumlah 8 poin. Uji validitas dalam penelitian ini menggunakan program SPSS. Validititas suatu butir pertanyaan dapat dilihat pada hasil output SPSS pada tabel dengan judul Item-Total Statistic. Menilai kevalidan masing-masing butir pertanyaan dapat dilihat dari nilai Corrected item-Total Correlation masing-masing butir pertanyaan. Suatu butir pertanyaan dikatakan valid jika nilai $\mathrm{r}_{\text {hitung }}$ yang merupakan nilai dari Corrected item-Total Correlation. (Sugiyono, 2013).

\section{Uji Validitas Harga}

\begin{tabular}{|c|c|c|c|c|}
\hline \multicolumn{5}{|c|}{ Tabel 9. Hasil Uji Validitas Variabel Harga } \\
\hline \multicolumn{5}{|c|}{ ITEM-TOTAL STATISTICS } \\
\hline NO & $\begin{array}{c}\text { SCALE MEAN IF } \\
\text { ITEM DELETED }\end{array}$ & $\begin{array}{c}\text { SCALE VARI- } \\
\text { ANCE IF ITEM } \\
\text { DELETED }\end{array}$ & $\begin{array}{c}\text { CORRECTED } \\
\text { ITEM-TOTAL } \\
\text { CORRELATION }\end{array}$ & $\begin{array}{c}\text { CRONBACH'S } \\
\text { ALPHA IF ITEM } \\
\text { DELETED }\end{array}$ \\
\hline$X_{1} .1$ & 31.83 & 19.779 & .597 & .765 \\
\hline$X_{1} .2$ & 31.97 & 19.747 & .582 & .767 \\
\hline$X_{1} .3$ & 31.80 & 18.707 & .677 & .753 \\
\hline$X_{1} .4$ & 32.38 & 22.056 & .348 & .795 \\
\hline$X_{1} .5$ & 31.22 & 23.042 & .302 & .798 \\
\hline$X_{1} .6$ & 31.72 & 20.244 & .577 & .768 \\
\hline$X_{1} .7$ & 31.57 & 20.753 & .605 & .767 \\
\hline$X_{1} .8$ & 32.36 & 21.667 & .385 & .791 \\
\hline$X_{1} .9$ & 31.11 & 24.038 & .310 & .798 \\
\hline$X_{1} \cdot 10$ & 32.01 & 20.939 & .361 & .799 \\
\hline
\end{tabular}

Pada tabel 9 terlihat bahwa seluruh item yang diuji memiliki $\mathrm{r}_{\text {hitung }}$ lebih besar dari nilai $\mathrm{r}_{\text {tabel }}$ $(0,197)$ sehingga dikatakan bahwa item kuesioner variabel harga adalah valid dan dapat digunakan untuk proses pengolahan data berikutnya. 


\section{Uji Validitas Promosi}

\begin{tabular}{|c|c|c|c|c|}
\hline \multicolumn{5}{|c|}{ Tabel 10. Hasil Uji Validitas Variabel Promosi } \\
\hline ITEM-TOTAL STATISTICS \\
\hline $\mathrm{X}_{2} \cdot 1$ & 30.93 & 25.719 & .622 & .799 \\
\hline $\mathrm{X}_{2} \cdot 2$ & 31.10 & 26.377 & .583 & .804 \\
\hline $\mathrm{X}_{2} \cdot 3$ & 30.91 & 26.043 & .566 & .805 \\
\hline $\mathrm{X}_{2} \cdot 4$ & 30.95 & 22.824 & .700 & .788 \\
\hline $\mathrm{X}_{2} \cdot 5$ & 30.90 & 23.479 & .674 & .792 \\
\hline $\mathrm{X}_{2} \cdot 6$ & 30.87 & 26.319 & .583 & .804 \\
\hline $\mathrm{X}_{2} \cdot 7$ & 30.82 & 27.456 & .555 & .808 \\
\hline $\mathrm{X}_{2} \cdot 8$ & 31.51 & 30.150 & .270 & .830 \\
\hline $\mathrm{X}_{2} \cdot 9$ & 30.71 & 28.515 & .321 & .829 \\
\hline $\mathrm{X}_{2} \cdot 10$ & 31.40 & 29.549 & .227 & .836 \\
\hline
\end{tabular}

Pada tabel 10 terlihat bahwa seluruh item yang diuji memiliki $\mathrm{r}_{\text {hitung }}$ lebih besar dari nilai $r_{\text {tabel }}(0,197)$ sehingga dikatakan bahwa item-item yang mewakili variabel promosi sudah valid dan boleh digunakan untuk proses pengolahan data berikutnya.

\section{Uji Validitas Keputusan Pembelian}

\begin{tabular}{|c|c|c|c|c|}
\hline \multicolumn{5}{|c|}{ ITEM-TOTAL STATISTICS } \\
\hline NO & $\begin{array}{l}\text { SCALE MEAN IF } \\
\text { ITEM DELETED }\end{array}$ & $\begin{array}{l}\text { SCALE VARI- } \\
\text { ANCE IF ITEM } \\
\text { DELETED }\end{array}$ & $\begin{array}{c}\text { CORRECTED } \\
\text { ITEM-TOTAL } \\
\text { CORRELATION }\end{array}$ & $\begin{array}{l}\text { CRONBACH'S } \\
\text { ALPHA IF ITEM } \\
\text { DELETED }\end{array}$ \\
\hline$X_{3} \cdot 1$ & 33.68 & 46.220 & .781 & .899 \\
\hline$x_{3} \cdot 2$ & 33.53 & 47.747 & .795 & .899 \\
\hline$X_{3} \cdot 3$ & 32.57 & 56.591 & .370 & .920 \\
\hline$X_{3} \cdot 4$ & 33.51 & 48.192 & .761 & .901 \\
\hline$x_{3} \cdot 5$ & 33.49 & 46.576 & .769 & .900 \\
\hline$X_{3} \cdot 6$ & 32.73 & 55.492 & .666 & .912 \\
\hline$X_{3} .7$ & 33.60 & 47.859 & .769 & .900 \\
\hline$X_{3} .8$ & 33.36 & 54.536 & .517 & .914 \\
\hline$X_{3} .9$ & 33.72 & 44.163 & .759 & .903 \\
\hline$X_{.} .10$ & 33.53 & 47.181 & .759 & .901 \\
\hline
\end{tabular}

Pada tabel 11 terlihat bahwa seluruh item yang diuji memiliki $\mathrm{r}_{\text {hitung }}$ lebih besar dari nilai $r_{\text {tabel }}(0,197)$ sehingga dikatakan bahwa item-item yang mewakili variabel keputusan pembelian sudah valid dan boleh digunakan untuk proses pengolahan data berikutnya.

\section{Uji Reliabilitas}

Uji reliabilitas digunakan untuk mengetahui kestabilan dan konsistensi alat ukur yang biasanya menggunakan kuesioner. Yang dimaksud adalah apakah alat ukur tersebut akan mendapatkan pengukuran yang tetap konsisten jika diulang kembali. Dalam melakukan uji reliabilitas peneliti menggunakan program SPSS versi 24 . Pada hasil uji reliabilitas dapat dilihat pada tabel Reliabillity Statistics pada output SPSS. Penentuan apakah instrument penelitian reliabel atau tidak, dilakukan dengan melihat nilai Cronbach's Alpha. Menurut (Latan \& Temalagi, 2013), suatu konstruk atau variabel dinyatakan reliabel jika menghasilkan nilai Cronbach's Alpha > 0,7, walaupun nilai 0,6 - 0,7 masih dapat diterima.

\section{a. Uji Reliabilitas Harga}

\begin{tabular}{|c|c|}
\hline \multicolumn{2}{c|}{ Tabel 12. Hasil Uji Reliabilitas Harga } \\
RELLABLITY STATISTICS \\
\hline CRONBACH'S ALPHA & NOF ITEMS \\
\hline .799 & 10 \\
\hline
\end{tabular}

Seperti yang terlihat pada tabel 12 nilai Cronbach's Alpha yang diperoleh adalah 0,799. Karena nilai tersebut > 0,60 maka dapat dikatakan cukup baik dari item-item pernyataan yang mewakili variabel harga memiliki reliabilitas yang baik.

\section{b. Uji Reliabilitas Promosi}

\begin{tabular}{|c|c|}
\hline \multicolumn{2}{|c|}{ Tabel 13. Hasil Uji Reliabilitas Promosi } \\
\hline \multicolumn{2}{|c|}{ RELIABILITY STATISTICS } \\
\hline CRONBACH'S ALPHA & NOF ITEMS \\
\hline .826 & 10 \\
\hline
\end{tabular}

Seperti yang terlihat pada tabel 13 nilai Cronbach's Alpha yang diperoleh adalah 0,826. Karena nilai tersebut $>0,60$ maka dapat dikatakan cukup baik dari item-item pernyataan yang mewakili variabel promosi memiliki reliabilitas yang baik.

\section{c. Uji Reliabilitas Keputusan Pembelian (Y)}

\begin{tabular}{|c|c|}
\hline \multicolumn{2}{|c|}{ Tabel 14. Hasil Uji Reliabilitas Keputusan Pembelian } \\
\hline \multicolumn{2}{|c|}{ RELIABILLTY STATISTICS } \\
\hline CRONBACH'S ALPHA & NOF ITEMS \\
\hline .914 & 10 \\
\hline
\end{tabular}

Seperti yang terlihat pada tabel 14 nilai Cronbach's Alpha yang diperoleh adalah 0,914. 
Karena nilai tersebut $>0,60$ maka dapat dikatakan cukup baik dari item-item pernyataan yang mewakili variabel keputusan pembelian memiliki reliabilitas yang baik.

\section{Koefisien Korelasi}

Uji Korelasi Pearson dilakukan untuk mengetahui seberapa besar hubungan antara variabel Promosi $\left(\mathrm{X}_{1}\right)$, Kualitas Produk $\left(\mathrm{X}_{2}\right)$, Kualitas Pelayanan $\left(\mathrm{X}_{3}\right)$, dan Suasana Tempat $\left(\mathrm{X}_{4}\right)$. Untuk melihat nilai koefisien korelasi berkisar antara 0 sampai 1 atau nilai semakin mendekati 1 maka hubungan semakin erat, jika mendekati 0 maka hubungan semakin lemah. Untuk melihat nilai koefisien korelasi dapat dibantu melalui program SPSS 24 yang menghasilkan output SPSS sebagai berikut :

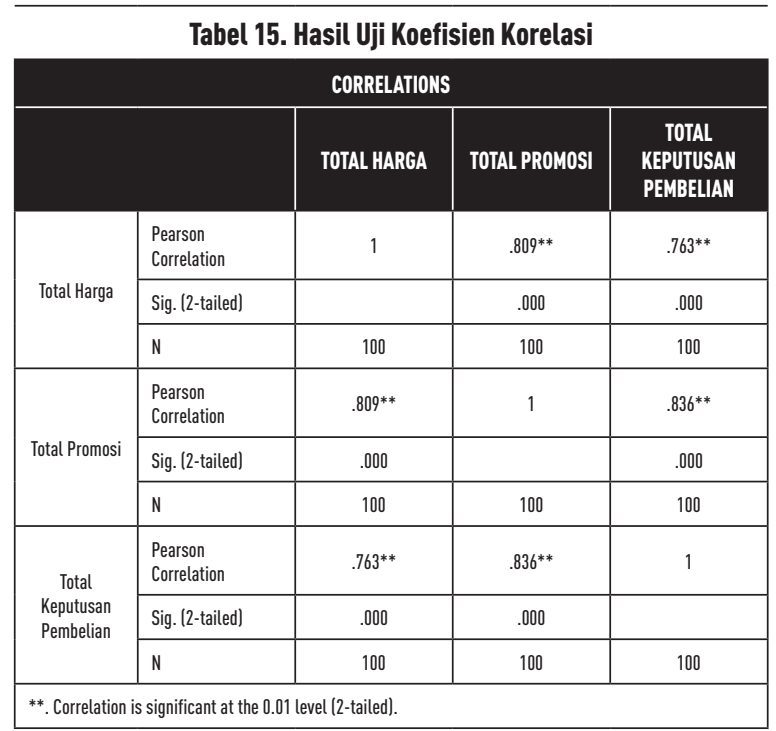

Dari tabel correlation diatas dapat dilihat hubungan korelasi tiap variabel, tingkat kekuatan korelasi variabel dan hubungan signifikannya. Kesimpulannya adalah:

a. Tingkat signifikan antara harga $\left(\mathrm{X}_{1}\right)$ terhadap keputusan pembelian (Y) yaitu signifikan sebesar $0,00<0,05$, dan hubungan antara harga $\left(\mathrm{X}_{1}\right)$ dengan keputusan pembelian $(\mathrm{Y})$ menunjukkan hubungan yang kuat, karena memiliki tingkat korelasi sebesar 0,763 yang mendekati angka 1. Angka koefisien juga menunjukkan angka positif artinya apabila harga $\left(\mathrm{X}_{1}\right)$ ditingkatkan, maka keputusan pembelian (Y) juga akan meningkat, begitu dengan sebaliknya apabila harga $\left(\mathrm{X}_{1}\right)$ ditu- runkan/menurun maka keputusan pembelian (Y) juga akan menurun.

b. Tingkat signifikan antara promosi $\left(\mathrm{X}_{2}\right)$ terhadap keputusan pembelian $(\mathrm{Y})$ yaitu signifikan sebesar $0,00<0,05$, dan hubungan antara promosi $\left(\mathrm{X}_{2}\right)$ dengan keputusan pembelian (Y) menunjukkan hubungan yang kuat, karena karena memiliki tingkat korelasi sebesar 0,836 yang mendekati angka 1 . Angka koefisien juga menunjukkan angka positif artinya apabila promosi $\left(\mathrm{X}_{2}\right)$ ditingkatkan, maka keputusan pembelian (Y) juga akan meningkat, begitu dengan sebaliknya apabila promosi $\left(\mathrm{X}_{2}\right)$ diturunkan/menurun maka keputusan pembelian (Y) juga akan menurun.

\section{Uji Heteroskedastisitas}

Uji heteroskedastisitas menyebabkan penaksir atau estimator menjadi tidak efisien dan nilai uji heteroskedastisitas merupakan keadaan di mana terjadinya ketidaksamaan varian dari residual pada model regresi. Model regresi yang baik mensyaratkan tidak adanya masalah heteroskedastisitas koefisien determinasi akan menjadi sangat tinggi. Untuk mendeteksi ada atau tidaknya heteroskedastisitas dapat dilihat pola-pola atau titik-titik pada scatterplot regresi. Jika titiktitik menyebar dengan pola tidak jelas diatas dan dibawah angka 0 maka tidak terjadi masalah heteroskedastisitas.

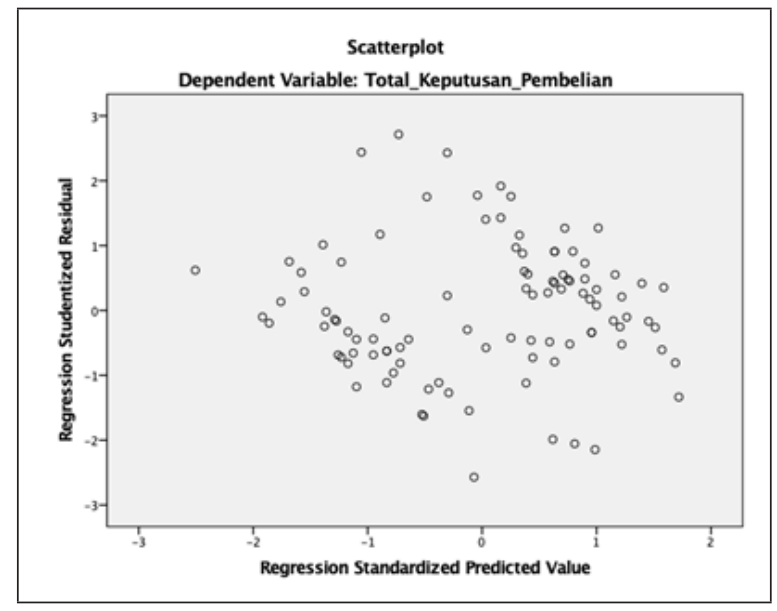

Gambar 3. Gambar Scatterplot Variabel Keputusan Pembelian

Pada gambar 3 output SPSS uji heteroskedastisitas menunjukkan penyebaran titik-titik 
data menyebar membentuk suatu pola dan tidak menyebar dengan rata dan tidak menyebar disekitar angkat 0 . Untuk mengetahui apakah variabel independen layak digunakan dalam penelitian atau tidak dan tidak terjadi heteroskedastisitas. Maka penulis melakukan uji Glejser pada tabel 17 sebagai berikut:

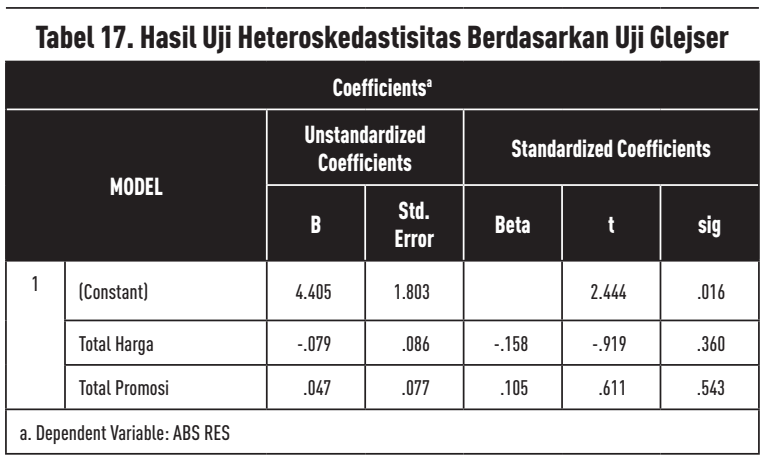

Pada tabel 17 Output SPSS uji Heteroskedastisitas berdasarkan uji Glejser menunjukan nilai Sig. :

a. Variabel promosi $\left(\mathrm{X}_{1}\right)$ sebesar $0,360>0,05$ yang berarti variabel harga $\left(\mathrm{X}_{1}\right)$ layak untuk digunakan dalam penelitian.

b. Variabel promosi $\left(\mathrm{X}_{2}\right)$ sebesar 0,543 $>0,05$ yang berarti variabel promosi $\left(\mathrm{X}_{2}\right)$ layak untuk digunakan dalam penelitian.

Dapat dinyatakan bahwa dalam model regresi tidak terjadi heteroskedastisitas antar variabel independen (bebas) sehingga data tersebut dapat digunakan untuk penelitian selanjutnya.

\section{Hasil Analisis Regresi Linier Berganda}

Analisis regresi linier berganda bertujuan untuk menguji pengaruh antara satu variabel dengan variabel lainnya dan melihat hasil dari variabel yang diteliti apakah bernilai positif atau negatif. Pada pengujian hipotesis ini digunakan untuk menguji pengaruh harga (X1), promosi (X2) terhadap keputusan pembelian (Y). Hasil dari regresi linier berganda dapat dilihat pada tabel 18 berikut ini :

Berdasarkan Tabel 4.17 diatas diketahui persamaan regresi yang terbentuk yaitu :

$$
\begin{aligned}
Y= & a+\beta_{1} X_{1}+\beta_{2} X_{2}+\beta 3 X_{3}+e \\
Y= & -6.587+0,386 X_{1}+0,873 X_{2} \\
& (0,007)(0,000)
\end{aligned}
$$

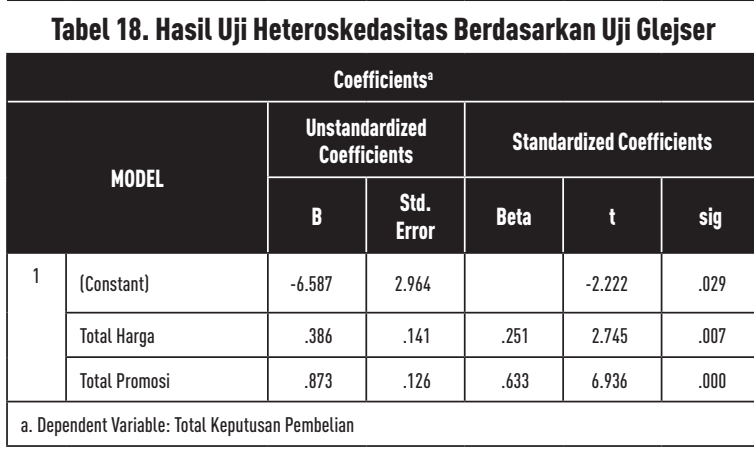

Dimana :

$\mathrm{Y}=$ Keputusan Pembelian

$\mathrm{X}_{1}=$ Harga

$\mathrm{X}_{2}=$ Promosi

$\mathrm{a}=$ Konstanta

$\beta_{1}, \beta_{2}=$ Angka Koefisien Regresi

e $=$ Standard Error

Persamaan regresi diatas dapat diinterprestasikan sebagai berikut:

a. Konstanta -6.587 memiliki arti : jika harga $\left(\mathrm{X}_{1}\right)$ dan promosi $\left(\mathrm{X}_{2}\right)$ nilainya 0 atau tidak memiliki pengaruh, maka keputusan pembelian (Y) nilainya sebesar -6.587 .

b. Koefisien regresi $(\beta) \mathrm{X}_{1}$ mempunyai nilai sebesar 0,386 memberikan arti bahwa harga $\left(\mathrm{X}_{1}\right)$ sebesar 1 maka akan mengakibatkan peningkatan keputusan pembelian $(\mathrm{Y})$ sebesar 0,386 .

c. Koefisien regresi $(\beta) \mathrm{X}_{2}$ mempunyai nilai sebesar 0,873 memberikan arti bahwa promosi $\left(\mathrm{X}_{2}\right)$ sebesar 1 maka akan mengakibatkan peningkatan keputusan pembelian (Y) sebesar 0,873

\section{Uji Analisis Parsial Koefisien (Uji t)}

Uji hipotesis parsial koefisien (uji t) dilakukan untuk mengetahui apakah variabel bebas secara parsial ada pengaruh signifikan signifikan terhadap variabel terikat. Pada uji ini dilakukan dengan cara membandingkan $\mathrm{t}_{\text {hitung }}$ dengan $\mathrm{t}_{\text {tabel }}$ sehingga sering disebut uji t. Degree of freedom pada uji t adalah n-k-1 di mana $\mathrm{n}$ (jumlah data), $\mathrm{k}$ (jumlah variabel independen).

Hipotesis:

$\mathrm{H}$ : Variabel bebas secara parsial tidak memiliki pengaruh yang signifikan terhadap variabel terikat. 
H: Variabel bebas secara pasial memiliki pengaruh signifikan terhadap variabel terikat.

\begin{tabular}{|c|c|c|c|c|c|c|}
\hline \multicolumn{7}{|c|}{ Tabel 19. Uji Analisis Secara Parsial (Uji t) } \\
\hline \multicolumn{7}{|c|}{ Coefficieients ${ }^{3}$} \\
\hline & \multirow{2}{*}{ MODEL } & \multicolumn{2}{|c|}{$\begin{array}{l}\text { Unstandardized } \\
\text { Coefficients }\end{array}$} & \multicolumn{3}{|c|}{ Standardized Coefficients } \\
\hline & & B & $\begin{array}{l}\text { Std. } \\
\text { Error }\end{array}$ & Beta & $t$ & sig \\
\hline \multirow[t]{3}{*}{1} & (Constant) & -6.587 & 2.964 & & -2.222 & .029 \\
\hline & Total Harga & .386 & .141 & .251 & 2.745 & .007 \\
\hline & Total Promosi & .873 & .126 & .633 & 6.936 & .000 \\
\hline
\end{tabular}

Aturan dalam t hitung:

a. Jika $-\mathrm{t}_{\text {hitung }}<-\mathrm{t}_{\text {tabel }}$ atau $\mathrm{t}_{\text {hitung }}>\mathrm{t}_{\text {tabel }} \rightarrow \mathrm{H}_{0}$ ditolak sehingga $\mathrm{H}_{a}$ diterima (signifikan).

b. Jika-tabel $\leq-\mathrm{t}_{\text {hitung }} \rightarrow \mathrm{H}_{0}$ diterima sehingga $\mathrm{H}_{\mathrm{a}}$ ditolak (tidak signifikan).

Atau dapat juga menggunakan nilai signifikan:

a. Jika Sig $<0,05 \rightarrow \mathrm{H}_{0}$ ditolak sehingga $\mathrm{H}_{a}$ diterima (signifikan).

b. Jika Sig $>0,05 \rightarrow \mathrm{H}_{0}$ diterima sehingga $\mathrm{H}_{\mathrm{a}}$ ditolak (tidak signifikan).

Dalam menentukan nilai tabel menggunakan rumus $\mathrm{df}=\mathrm{n}-\mathrm{k}-1=100-4-1=95, \mathrm{n}$ adalah jumlah sampel dan $\mathrm{k}$ merupakan jumlah semua variabel independen. Dari hasil rumus diatas diperoleh hasil $\mathrm{t}_{\text {tabel }}$ sebesar 1,985 yang dilihat dari tabel $\mathrm{t} \mathrm{df}$ $=95$, yaitu baris 95 dari $\mathrm{t}_{\text {tabel }}$.

1. Variabel harga $\left(\mathrm{X}_{1}\right)$ memiliki $\mathrm{t}_{\text {hitung }}=2,745$; Sig $=0,007$

a. $\quad \mathrm{t}_{\text {hitung }}(2,745)>\mathrm{t}_{\text {tabel }}(1,985) \rightarrow$ maka $_{0}$ ditolak.

b. Nilai Sig. $0,007<0,05 \rightarrow$ maka $\mathrm{H}_{a}$ diterima.

Artinya, variabel harga $\left(\mathrm{X}_{1}\right)$ secara parsial memiliki pengaruh signifikan terhadap variabel keputusan pembelian (Y).

2. Variabel promosi $\left(\mathrm{X}_{2}\right)$ memiliki $\mathrm{t}_{\text {hitung }}=6,938$; Sig $=0,000$

a. $\mathrm{t}_{\text {hitung }}(6,938)>\mathrm{t}_{\text {tabel }}(1,985) \rightarrow$ maka $\mathrm{H}_{0}$ ditolak.

b. Nilai Sig. $0,000<0,05 \rightarrow$ maka $\mathrm{H}_{\mathrm{a}}$ diterima.

Artinya, variable promosi $\left(\mathrm{X}_{2}\right)$ secara parsial memiliki pengaruh signifikan terhadap variabel keputusan pembelian (Y). Hasil uji T menyatakan bahwa da- lam penelitian ini terdapat pengaruh signifikan secara parsial antara variabel harga dan promosi terhadap keputusan pembelian.

\section{Uji Kelayakan Model (Uji F)}

Uji kelayakan model yang popular disebut sebagai uji $\mathrm{F}$ atau biasa disebut dengan uji simultan model, merupakan tahapan untuk mengidentifikasi model regresi yang di estimasi layak digunakan untuk menjelaskan pengaruh variabelvariabel bebas terhadap variabel terikat. Uji ini disebut dengan uji $\mathrm{F}$ karena mengikuti distribusi F yang kriteria pengujiannya seperti One Way Anova. Apabila nilai prob. $\mathrm{F}_{\text {hitung }}$ (sig) < tingkat kesalahan $(0,05)$ maka model regresi estimasi layak digunakan untuk menjelaskan pengaruh variabel-variabel bebas terhadap variabel terikat.

\begin{tabular}{|c|c|c|c|c|c|c|}
\hline \multicolumn{7}{|c|}{ Tabel 20. Uji Analisis Model Regresi } \\
\hline & MODEL & $\begin{array}{l}\text { Sum of } \\
\text { Squares }\end{array}$ & df & Mean Square & $\mathbf{F}$ & sig \\
\hline \multirow[t]{3}{*}{1} & Regression & 4317.128 & 2 & 2158.564 & 125.360 & $.000^{\circ}$ \\
\hline & Residual & 1670.232 & 97 & 17.219 & & \\
\hline & Total & 5987.360 & 99 & & & \\
\hline
\end{tabular}

Hasil uji F menyatakan bahwa dalam penelitian ini model regresi yang di Estimasi layak digunakan karena nilai prob. $\mathrm{F}_{\text {hitung }}$ (Sig) memiliki nilai $0,000<$ tingkat kesalahan $(0,05)$.

\section{Koefisien Determinasi (Adjusted $R^{2}$ )}

Pada tabel 21 dibawah ini menunjukkan koefisien determinasi dari model Koefisien Determinasi (Adjusted $R^{2}$ ).

\begin{tabular}{|c|c|c|c|c|c|c|}
\hline \multicolumn{7}{|c|}{ Model Summary } \\
\hline & MODEL & $\mathbf{R}$ & R Square & $\begin{array}{c}\text { Adjusted R } \\
\text { Square }\end{array}$ & $\begin{array}{l}\text { Std. Error of the } \\
\text { Estimate }\end{array}$ & $\begin{array}{l}\text { Durbin- } \\
\text { Watson }\end{array}$ \\
\hline 1 & \begin{tabular}{|l} 
Regression \\
\end{tabular} & $.849^{\mathrm{a}}$ & .721 & .715 & 4.150 & 1.452 \\
\hline
\end{tabular}

Pada tabel 21 dapat dilihat bahwa nilai $\mathrm{R}$ 0,849 mendekati angka 1 , sehingga dapat dikatakan bahwa hubungan antara harga $\left(\mathrm{X}_{1}\right)$ dan promosi $\left(\mathrm{X}_{2}\right)$ terhadap keputusan pembelian 
(Y) memiliki hubungan yang kuat. Untuk hasil koefisien determinasi (Adjusted $R^{2}$ ) sebesar 0,715 atau $71,5 \%$, angka tersebut berarti 71,5 keputusan pembelian dipengaruhi oleh harga dan promosi. Sedangkan sisanya sebesar $28,5 \%$ dipengaruhi oleh faktor-faktor lain yang tidak termasuk dalam penelitian ini. Std Error of the Estimate 4,150, artinya kesalahan yang dapat terjadi dalam memprediksi keputusan pembelian sebesar 4,15\%.

\begin{tabular}{|c|c|c|c|}
\hline \multicolumn{4}{|c|}{ Tabel 22. Rangkuman Hasil Analisis Korelasi dan Regresi } \\
\hline VARIABEL & $\begin{array}{c}\text { KOEFESIEN REGRESI } \\
\text { (BETA) }\end{array}$ & $\begin{array}{c}\text { KOEFESIEN } \\
\text { KORELASI (R) }\end{array}$ & R SQUARE \\
\hline$X_{1}$ & 0,251 & $.763^{* *}$ & .721 \\
\hline$X_{2}$ & 0,633 & $836^{* *}$ & \\
\hline
\end{tabular}

Rumus untuk menghitung Sumbangan Efektif (SE) :

$\mathrm{SE}(\mathrm{X}) \%=$ Betax $\mathrm{x}$ Koefesien Korelasi $\mathrm{x}$ $100 \%$ atau SE $(\mathrm{X}) \%=$ Betax $\mathrm{x}$ rxy $\mathrm{x} 100 \%$

Sumbangan Efektif Variabel Harga $\left(\mathrm{X}_{1}\right)$ Terhadap Keputusan Pembelian (Y)

$\mathrm{SE}\left(\mathrm{X}_{1}\right) \%=$ BetaX $_{1} \times \mathrm{rxy} \times 100 \%$

$\mathrm{SE}\left(\mathrm{X}_{1}\right) \%=0,251 \times 0,763 \times 100 \%$

$\mathrm{SE}\left(\mathrm{X}_{1}\right) \%=19,2 \%$

Sumbangan Efektif Variabel Promosi $\left(\mathrm{X}_{2}\right)$ Terhadap Keputusan Pembelian (Y)

$\mathrm{SE}\left(\mathrm{X}_{2}\right) \%=$ BetaX $_{2} \mathrm{x} \operatorname{rxy} \times 100 \%$

$\operatorname{SE}\left(\mathrm{X}_{2}\right) \%=0,633 \times 0,836 \times 100 \%$

$\operatorname{SE}\left(\mathrm{X}_{2}\right) \%=52,9 \%$

Sumbangan Efektif (SE) total dapat dihitung sebagai berikut:

SE total $\quad=\operatorname{SE}\left(\mathrm{X}_{1}\right) \%+\mathrm{SE}\left(\mathrm{X}_{2}\right) \%$

SE total $=19,2 \%+52,9 \%$

SE total $=72,1 \%$

Kesimpulan Sumbangan Efektif Variabel:

Berdasarkan hasil perhitungan diatas dapat diketahui bahwa sumbangan efektif (SE) variabel harga $\left(\mathrm{X}_{1}\right)$ terhadap keputusan pembelian $(\mathrm{Y})$ adalah sebesar 19,2\%. Sementara sumbangan efektif (SE) variabel promosi $\left(\mathrm{X}_{2}\right)$ terhadap keputusan pembelian (Y) adalah sebesar 52,9\%. Dengan demikian dapat disimpulkan bahwa variabel $\mathrm{X}_{2}$ memiliki pengaruh lebih dominan terhadap variabel $\mathrm{Y}$ dari pada variabel $\mathrm{X}_{1}$. Untuk total SE adalah sebesar $72,1 \%$ atau sama dengan koefisien determinasi (Rsquare) analisis regresi yakni $72,1 \%$.

\section{SIMPULAN}

Harga yang ditawarkan oleh Story-I Mall Alam Sutera di persepsikan baik. Hal ini dapat dilihat pada poin nomor 1 mengenai diskon yang diberikan Story-I Mall Alam Sutera mempengaruhi pelanggan untuk membeli dan pada poin 9 mengenai pelanggan tertarik dengan adanya penawaran pembayaran secara kredit mendapatkan hasil jawaban responden dengan ratarata skor 3,48 berada pada rentang skor 3,41-4,20 atau masuk pada kategori baik.

Promosi yang ditawarkan oleh Story-I Mall Alam Sutera di persepsikan baik. Hal ini dapat dilihat pada poin 7 mengenai pelanggan mendapatkan potongan harga berupa voucher pada saat pembelian dan pada poin 9 mengenai karyawan memberikan informasi up to date mengenai produk baru mendapatkan hasil jawaban responden dengan rata-rata skor 3,44 berada pada rentang skor 3,41-4,20 atau masuk pada kategori baik.

Keputusan Pembelian yang ditawarkan oleh Story-I Mall Alam Sutera di persepsikan baik. Hal ini dapat dilihat pada poin 3 mengenai terbiasa membeli produk di Story-I Mall Alam Sutera dan poin 6 mengenai membeli di Story-I Mall Alam Sutera karena lokasinya yang strategis mendapatkan hasil jawaban responden dengan rata-rata skor 3,71 berada pada rentang skor 3,414,20 atau masuk pada kategori baik.

Terdapat pengaruh positif dan signifikan antara harga dan promosi terhadap keputusan pembelian dengan persamaan regresi $\mathrm{Y}=-6.587$ $+0,386 X_{1}+0,873 X_{2}$, konstanta $-6,587$, koefisien regresi $\mathrm{X} 1$ sebesar 0,386 dan koefisien regresi $\mathrm{X}_{2}$ sebesar 0,873 sedangkan nilai korelasinya atau $\mathrm{r}$ $X_{1}$ sebesar 0,764 dan $X_{2}$ sebesar 0,836 dan nilai koefisien determinasi (Kd) sebesar 0,849 atau $71,5 \%$ sedangkan sisanya sebesar $28,5 \%$ dipengaruhi faktor lain.

Pengujian hipotesis menggunakan uji statistik $\mathrm{t}_{\text {hitung }}$ untuk variabel harga diperoleh $\mathrm{t}_{\text {hitung }}$ $(2,745)>t_{\text {tabel }}(1,985)$ dan nilai signifikan 0,007 < $0,05 \rightarrow$ maka $\mathrm{H}_{0}$ ditolak dan $\mathrm{H}_{1}$ diterima. Variabel promosi diperoleh $\mathrm{t}_{\text {hitung }}(6,938)>\mathrm{t}_{\text {tabel }}(1,985)$ dan nilai signifikan $0,000<0,05 \rightarrow$ maka $_{0}$ ditolak dan $\mathrm{H}_{1}$ diterima, artinya terdapat pengaruh signifikan 
secara parsial antara variabel harga dan promosi terhadap keputusan pembelian. Diketahui Ftabel $=3.09$ dan $\mathrm{F}_{\text {hitung }}=125.360$. Karena $\mathrm{F}_{\text {hitung }}>\mathrm{F}_{\text {tabel }}$, maka $\mathrm{H}_{0}$ ditolak, dan $\mathrm{H}_{a}$ diterima sehingga variabel harga, dan promosi berpengaruh signifikan terhadap keputusan pembelian pada Story-I Mall Alam Sutera, secara SPSS yaitu dengan melihat probabilitas signifikansinya (P-value) $=0,000$ atau $0 \%$ lebih kecil dari 5\% maka $\mathrm{H}_{0}$ ditolak, $\mathrm{H}_{\mathrm{a}}$ diterima sehingga dapat dikatakan bahwa variabel harga, dan promosi berpengaruh signifikan terhadap keputusan pembelian pada Story-I Mall Alam Sutera.

\section{DAFTAR PUSTAKA}

Aji, N. Setio. Djawahir, A. H. (2019). The Influence Of Products And Promotions On Purchasing Decisions Mediated In Purchase Motivation. Journal of Applied Management (JAM), 17(March 2019), 152-161.

Herawati. Prajanti, S. D. W. K. (2019). Predicted Purchasing Decisions from Lifestyle, Product Quality and Price Through Purchase Motivation. Journal of Economic Education, 8(June 2019), 1-11.

Kotler, P. (2005). Armstrong.(2012). Principles of Marketing, 14.

Kotler, P., Keller, K. L., Brady, M., Goodman, M., \& Hansen, T. (2012). Marketing Management. England.

Kurniawan, D., \& Widajanti, E. (2016). Pengaruh promosi dan harga terhadap keputusan pembelian rokok Djarum Super dengan kepuasan konsumen sebagai variabel moderasi. Jurnal Ekonomi Dan Kewirausahaan, 15(3), 354366.

Latan, H., \& Temalagi, S. (2013). Analisis Multivariate Teknik dan Aplikasi Menggunakan Program IBM SPSS 20.0. Bandung: Alfabeta.

Senggetang, V., Mandey, S. L., \& Moniharapon, S. (2019). Pengaruh Lokasi, Promosi dan Persepsi Harga Terhadap Keputusan Pembelian Konsumen Pada Perumahan Kawanua Emerald City Manado. Jurnal Riset Ekonomi, Manajemen, Bisnis Dan Akuntansi, 7(June 2109), 1-11.
Sofjan, A. (2013). Strategic Management, Sustainable Competitive Advantages. Jakarta: PT. Raja Grapindo Persada.

Sugiyono. (2011). Statistika untuk Penelitian. Bandung: Alfabeta.

Sugiyono. (2013). Metode Penelitian Manajemen. Bandung: Alfabeta.

Sugiyono. (2016). Metode Penelitian Kualitatif, Kuantitatif dan ReD. Bandung: Alfabeta.

Sujarweni, V. W. (2015). Metodologi Penelitian Bisnis \& Ekonomi. Yogyakarta: Paper Plane.

Sunyoto, D. (2013). Teori, Kuesioner \& Analisis Data Untuk Pemasaran dan Perilaku Konsumen. Yogyakarta: Graha Ilmu.

Tjiptono, F. (2011). Pemasaran Jasa. Malang: Bayumedia.

Tjiptono, F. (2015). Strategi Pemasaran (Edisi Keempat). Yogyakarta: Andi. 